before being taken into the modifying room." (R. F. Taylor).

For a long time it was assumed that the composition of human milk varied with the age of the child, but Professor Leeds' long series of analyses show that after the function of lactation is once fairly es. tablished, the composition of woman's milk remains practically the same; and while the child receives more nutriment, day by day, it is in consequence of larger doses, rather than of a stronger quality. This is quite in harmony with reason and common sense.

Now if we wish to order a humanized milk as prepared at these laboratories, say for a child one month old, we would order the following mixture:

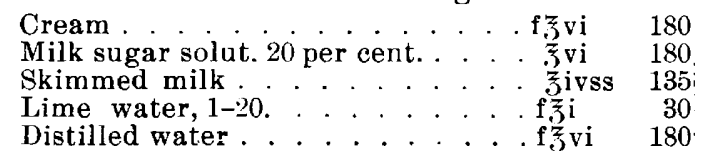

This is divided into twelve feedings, 2 ounces each. As the infant grows older, the intervals are lengthened and the doses increased. A child from two to five months old should receive eight feedings of 4 ounces each, and a strong child from five to eight months old, may receive from 6 to 7 ounces at each of the eight feedings, according to the indications which are best studied by the weight chart. Professor Rotch uses lime water for the purpose of partially neutralizing the acidity of the gastric juice, in consequence of which the casein coagulates nore slowly and the formation of firm undigestible curds is thus prevented. Professor Leeds, instead of lime water, strongly recommends the addition of peptogenic milkpowder, which is a preparation of pancreatic lactose and alkalin milk salts, originated by Fairchild Brothers \& Foster of New York.

There is nothing strained in the requirement of an ideal milk supply, as good and sufficient reasons have been given, and by means of which we may hope to obtain such a standard of milk as will not only effect a decided reduction in infantile mortality, but will render the dissemination of infectious diseases through the milk supply a matter of history only. Apart from these advantages the proper way to manufacture condensed milk suitable for infant feeding is to modify the milk before evaporation, a plan which, as far as I know, has not been attempted and is urgently called for.

In the meantime, it will be well to educate the public in the matter of milk sediments, which can readily be seen at the bottom of the bottle after a few hours standing. If we tell our dairyman the source of this pollution and how it can be prevented, something will be accomplished. No milk supply is absolutely safe without pasteurization; and for infant feeding, until we can do better, $[$ advise the following combination recommended by Professor Leeds:

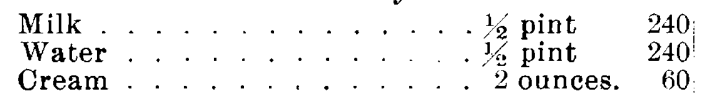

Peptogenic milk powder one large measure. This mixture should be placed on a hot range or gas stove and with constant stirring slowly heated for ten minutes to bring it to the boiling point; it is then removed and quickly cooled, and should be kept on ice and again pasteurized before feeding. While milk thus prepared can never take the place of breast-milk from a bealthy mother, it is very near in all respects to human milk and is perfectly sterile, as far as the ordinary disease germs are concerned.
Prevention of disease is perhape the central idea and object of sanitarians, but as hygiene also deals with the art of improving health, the question of a pure milk supply is not only important in the feeding of infants, but also the sick and invalids, and I trust, therefore, one of general interest to the profession.

\section{A CONTRIBUTION TO THE STUDY OF ATRESIA OF THE UTERINE CANAL AFTER THE MENOPAUSE, WITH A REPORT OF THREE CASES.}

Read before the Medical Society of the District of Columbia, June 12, 189.5 BY HENRY L. E. JOHNSON, M.D.

MEMISER OF THE FIRST PAN-AMERICAN MEDICAL CONGRESS; LATE VICFPRESIDENT OF THE WASHINGTON OLSTETRICAL AND GYNECOLOGICA I SOCIETY; PROFESSOR OF GYNECOLOGY IN THE MEDICAL DEPART MENT OF THE COLUMBIAN UNIVERSITY ; DIRECTOR OF THE GYNECOLOGIC CIINIC IN THE CENTRA], DISPENSARI AND EYERGENCY HOSPITAL, ETC. WASHINGTON, D. C.

Some years ago, when I was learning my first lessons in clinical gynecologic practice in a hospital devoted especially to that department of medicine, I had the good fortune to see and make the diagnosis of atresia of the vagina with retention of menses in a young woman, and later on, a case of atresia of the cervix uteri in an old lady who had passed the climacteric period several years. In the first case, operation was had, which resulted in cure. The second case presented many symptoms, some local, but particularly manifested in the nervous system. She was treated by medicines only and was not accorded an operation, and because no improvement followed was discharged from the hospital as a malingerer. After several years of invalidism she died of some "obscure disease."

I was taught that operation in such cases was contra-indicated, because menstruation had ceased, fluid accumulation being impossible, and surgical interference was attended with much danger and a high mortality. I will ask the society to bear with me while I give the history of some cases in which atresia of the cervical canal existed and for the relief of which operative interference was instituted with good results. The bibliography on the subject is also presented for your consideration, and you will see that the subject has not received the attention which it deserves when you learn the number and standing of the writers who make no mention of the condition.

HISTORY OF CASES.

Case 1.-On March 21 of the present year, I was consulted in $\mathrm{my}$ clinic at the Central Dispensary and Emergency Hospital by Mrs. L., age 54 years, white, married, one child, no miscarriages. She was born January, 1840 , enjoyed good health until 1866 , though always thin and never very strong. Family history excellent. First menstruated during the thirteenth year, that function being normal in every partieular. Married in 1863, and in due time was delivered of a healthy child. Labor and puerperium normal. Shortly after death of child, three years later, she first complained of "womb trouble" and consulted a number of physicians with more or less relief but was never entirely cured. Menses ceased in 1881 , since which time she has never been well. In July, 1887, after investigation and consultation she was committed to the United States Hospital for the Insane, and there treated for acute melancholia with hallucinations of persecution. She was shortly discharged, relieved but not cured. At that time she was very fleshy and bloated, notwithstanding the fact that she frequently refused her food. One year later she returned voluntarily to the hospital seeking admission in order to escape imaginary persecutors. She was not re-admitted because of lack of authority. She was at that time very thin and anemic. Since the cessation of the menses she has complained almost constantly of 
backache, pain in lower abdominal region, bearing down' frequent and painful urination, constant leucorrhea with irritation and excoriation of external genitals. Loss of appetite, coated tongue, indigestion, nausea, vomiting, meteorism and constipation, palpitation of heart, irregular pulse and vertigo. Occasional fever, chills, and sweatings, nervousness, insomnia, prostration, loss of flesh, alteration in functions of special senses (sight and hearing), slowness of speech and mental operations. Numbness, trembling and twitehing in limbs. Hysteria, hallucinations of impending danger and persecution and of sight and hearing.

Examination : very fat, color bad, pale and sallow; tongue coated and trembling, hands trembling, pulse rapid. Is very nervous. Abdomen enlarged and distended with gas; perineum lacerated to second degree; prolapse of mucous membrane of urethra ; vagina inflamed; muco-purulent discharge, and prolapse of anterior and posterior wall. Cervix uteri not discoverable by sight, entirely obliterated; no trace of os can be found; the supravaginal portion of cervix, however, can be determined by touch. Uterus small, but larger than normal at her age, soft, retroverted, fixed, tender on pressure. Both tubes enlarged, fluctuating, fixed and tender on pressure. Diagnosis: atresia of cervical canal, with retained fluid. Operation decided upon.

On March 24 , in presence of some of the college class, I seized the vault of the vagina at the site of the cervix with a volsellum forceps and introduced a curved bistoury about two inches and a half deep, into the tissues where $I$ had located the cervical canal. This was followed by an evacuation of about two or more ounces of greenish pus more or less offensive in odor. Subsequently irrigating the vagina with antiseptic solution and applying antiseptic applications on pledgets of sterilized cotton. Drainage of pus continued for two weeks with the occasional passage of hard inspissated lumps of pus and epithelium. Marked improvement in symptoms followed, with reduction in size of the tubes and uterus.

April 4, in the presence of some of the hospital assistants, I removed a ring of cervical tissue from around the incisson, making an oval opening considerably larger than a normal os. The mucus membrane intra and extracervical not stitched together, but the space allowed to heal by granulation. Shortly afterward all nervous intestinal and circulatory symptoms disappeared, and patient felt quite well. The local condition was much improved, though the uterus is still retroverted and somewhat fixed. This condition had evidently existed for a long period and has been a most important factor in the causation of her varied and numerous symptoms; in fact, it might be no exaggeration to infer that the local condition has been the only lesion. Within a few weeks, a prominent gynecologist here, after local examination, pronounced her free from any uterine disease and transferred her for treatment to a specialist in nervous diseases.

It is interesting to note the number and skill of the physicians who have at different times had charge of this case, none of whom, however, discovered the nature of the malady. This failure to recognize the Iesion is due almost entirely to the lack of, or faulty teaching in, the text-books, and it is hoped that this contribution will stimulate special study of these post-menopause cases.

Case \%.-Consulted me at the hospital on June 6 last, Mrs. IV. H., white, age 50 years; widow about one year; one child after marriage about thirty years ago. Labor normal, no miscarriage; menstruated between fourteenth and fifteenth year. Always strong and healthy and never had any womb trouble, so far as she knows. Never had a vaginal examination made since the birth of her child. Menses absent about four years and been sick during that time. Complains of backache, soreness in walking, bearing down pains, frequent urination and leucorrhea, loss of appetite, indigestion and constipation. Is very nervous and hysterical, with numbness and twitching in limbs; has been losing flesh for some time and can not sleep at night; has been having convulsions at intervals of two or three months for the past two years. During the past four years she has consulted a number of physicians, all of whom told her she had no womb trouble and none of them thought it necessary to make a vaginal examination, because " she had passed the change of Iife," and as they thought, gave no symptom of womb dis. ease. Examination: partial laceration of perineum, vagina inflamed, uterus small, soft and boggy; atresia of canal at internal os. Sound forced through obstruction and two or three ounces of muco-pus evacuated. Patient felt relief at once and described her sensation as if some tension or pressure had been removed. She has continued to improve and now feels better than she has for years. The same subsequent treatment was followed in this as in the preceding case.

It is fair to assume that this condition exists more frequently than is usually supposed, and many similar cases may be under treatment to-day in the asylums for the insane. The menopause being unquestionably a physiologic process should not be attended with the extraordinary symptoms which we witness in so many cases, the exception being found, I believe, in thos $\theta$ where the normal changes are interrupted or modified by pathologic conditions.

Clinically, all women passing through the change of life or menopause, do not have serious symptoms. and when exceptional cases are observed, we should conclude there is a cause for their complaints, and a thorough local examination should be instituted. In this department of medicine we should always bear in mind the possibility of this condition and its importance, when the lesion itself will be easily discovered and cured.

\section{PATHOLOGIC SPECIMEN.}

The unusual growth which I removed to-day, I will present for your consideration, because it presents an atresia of the cervical canal and obliteration of the infravaginal portion of the cervix and, practically, an atresia of the vagina at its extreme upper portion.

Mrs. $B$, age 58 years, married, several miscarriages. Been in ill health for sixteen years. Never had any flooding spells. Has had an enlargement of the abdomen for years but never knew until now she had a tumor. Has not menstruated for five jears and was very irregular for five years previous. Had a slight muco-sanguinous discharge two months ago, which lasted two or three days. Has been confined to bed for six months on account of pain in abdomen and neuralgia of face. Examination: abdomen enlarged to size of nine months' pregnancy by a large irregular fluctuating nodular mass, which is almost entirely confined to the right lateral portion of the abdomen and extending from deepest pelvic region to diaphragm. No trace of the cervix or os can be found. From absence of flooding, the soft, irregular and fluctuating character of the mass and its location, principally in the right side and absence of cervix and canal, I diagnosticated multilocular cyst of right ovary, and excluded the probability of fibroma. Just before making the incision, however, I gave reasons for excluding fibroid tumor, extraperitoneal (so-called abdominal) pregnancy, but admitted the possibility of the uterus being distended with fluid because of atresia of the cervical canal; though from the general character of the growth I did not believe it uterine, thinking that organ was atrophied. On section mistake in diagnoses noted.

Enlarged multiple fibroid was found with degenerated interior containing fluid, about two quarts offensive pus. A soft, stringy, friable mass was discovered growing from posterior surface of uterus, completely filling up the pelvic cavity and forcing the viscera above. The right Fallopian tube was about ten inches long, having attached to its fimbriated extremity a large fibroid ovary. Two large soft masses containing fluid were next reached. The first attached to the fundus uteri, the other superimposed upon the first, and attached firmly to the diaphragm above. The peritoneal cavity was distended with a large quantity of cherry-colored fluid. The masses were attached or adherent to themselves, the parietal, back, and pelvic walls, omentum, liver and intestines. The adhesions were freed; in some places thin layers of the cyst wall were removed and left attached to the intestines, complete separation being impossible. Notwithstanding the extensive adhesions neither omentum or intestines were in jured. The tumor was delivered and the uterine and ovarian arteries ligated. The mass was then easily excised, no hemorrhage following. A very excellent intraperitoneal stump was formed and covered by peritoneum, a small fibroid being removed from the 
stump, posterior to the bladder. The cavity was perfectly dry when the incision was closed, and the patient was placed in bed. Profound shock followed, patient dying within an hour, never regaining consciousness. The operation lasted one hour and forty minutes. Tumor weighed exclusive of fluid thirty-seven pounds.

After opening the abdomen the operation might have been abandoned, but the patient requested that the growth should be removed at all hazards. This case is a most instructive one, and shows how atresia with obliteration of the cervix may prevent an accurate diagnosis being made; and it is a particularly fit specimen to accompany this contribution. After its removal the uterine cavity was found very nuch distended, presumably with gas, physometra, contained no fluid and measured nine inches in diameter. But for the atresia and obliterated cervix the sound would have been of great assistance in diagnosis, and would have cleared up considerable doubt.

The report of the pathologists of the hospital, Drs. Gray and Parker, and that of Dr. Walter Reed, U.S.A., Curator of the Army Medical Museum, is herewith appended, together with the photographs of the grow th made by Dr. Church, the resident physician.

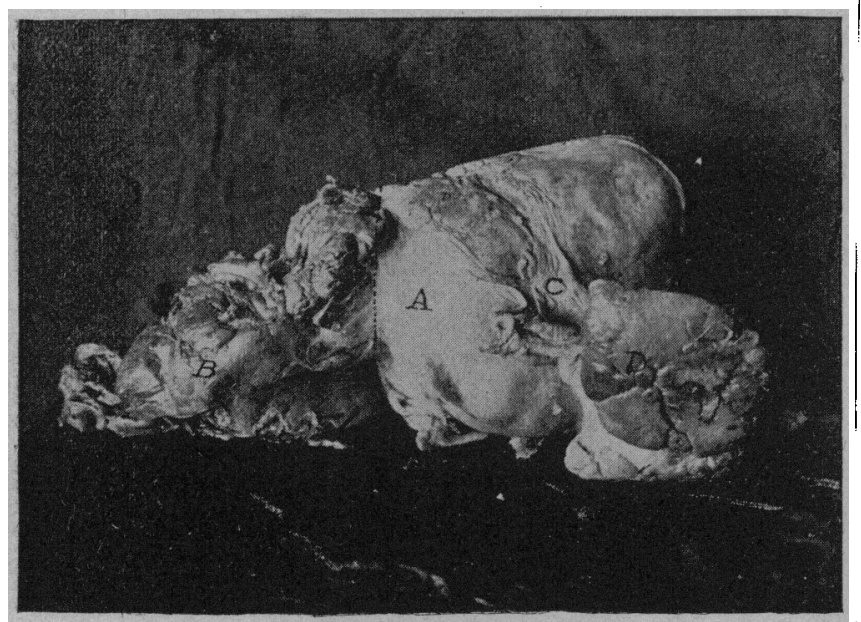

Fra. 1.-View from under side.

A. Fundus of uterus. B. Pelvic mass, from dotted line. C. Left broad ligament, and ovary. D. D. Masses attached to uterine fundus, and containing fluid.

Jionel Laboratory, Washingtox, D. C., June 28, 1895. Dr. H.L. E. Johnson.

Dear Doctor:-The sections from the tumor of uterus removed from Mrs. B. prove to be malignant in character. The growth is a sarcoma of a mixed variety; it is composed of round and spindle cells of various sizes.

The round white tumor which occupied the position of one of the ovaries is not malignant; it is a soft myxofibroma.

$$
\text { Yours truly, W. M. GRAY, }
$$

Pathologist Central Dispensary and Emergency Hospital.

WAR DEPARTMENT.

Surgeon-Generat's Office, U. S. Army Medical Meseum AND LimRary.

Wasinington, D. C., July 3, 1895.

Ir. H.L. E. Johnson, 1490 L. St. N. W., Washington, D. C.

Dear Joctor:-I beg to submit the following report of an examination of the specimen of uterus and appendages with tumor mass, which was received at the Museum on June 26 , 1895.

Dr. Lamb furnishes me with the following gross description of the specimen; the uterus, which has been removed at the internal os, is somewhat pyramidal in shape, and measures $6.5 \times 6.5 \times 7$. The enlargement is due partly to hypertrophy and partly to the fibroid growth, which latter is situated in the left wall and projects into the flattened uterine cavity. Within this fibroid there is a large cavity, with rough inner surface, filled with a recent blood clot. Projecting upward from the fundus are several large tumor masses, one of which is hollowed out into a cyst, with thick wall and rough inner surface, the latter bcing overspread with blood vessels. The right tube is adherent by its fimbriated end to the ovary; left tube normal. Right ovary converted into a firm fibrous-looking mass, $3 \times 2 \times 2$ inches in diameter; left ovary normal in size and structure; shows remains of corpora lutea. Posterior to the lower end of the uterus is a large shredded and brittle mass, covered on its upper side by the peritoneum of Douglas' cul-de-sac.

Microscopic examination of sections taken from different parts of the tumor mass show the structure of a mixed cell sarcoma, richly supplied with blood vessels. In several parts of the section there are seen cross sections of blood vessels with intact intima, and which are surrounded by dense masses of round and spindle-shaped cells, giving the picture of an angiosarcoma. Microscopic examination of

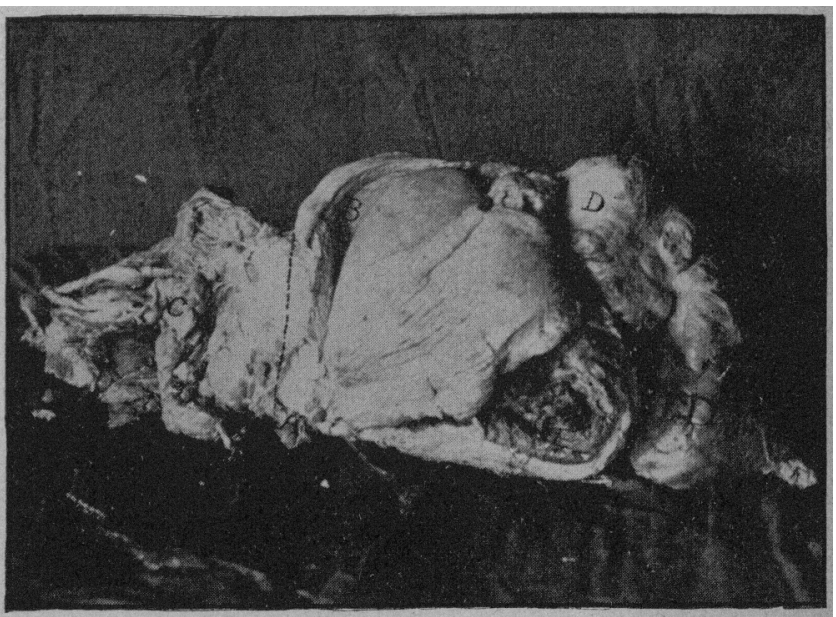

Fig. 2.- J.eft lateral view.

A. Cervix at point of amputation and atresia. B. Cavity of uterus laid open. C. Pelvic mass, from dotred line. D. D. Masses attached to uterine wall and containing fluid. E. Cavity of abscess, containing about two quarts pus. F. Fedicle attached to diaphragm.

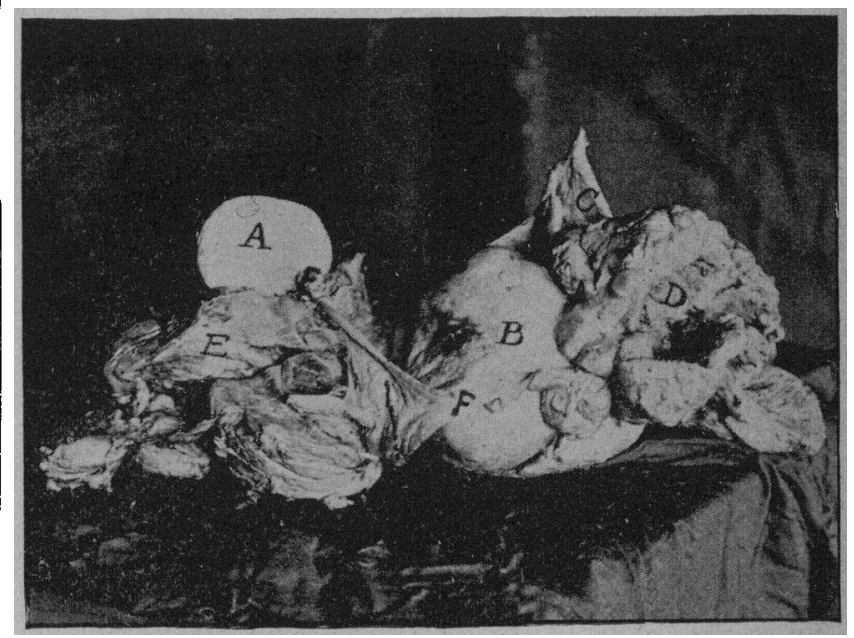

Fra. 3.- Right lateral view.

A. Fibroid ovary. B. Uterus. C. Normal ovary and broad ligament. D. Cavity of abscess. E. Pelvic mass, from dotted line. F. Long fillopian tube.

the small tumor mass occupying the position of the right ovary proves it to be a myxofibroma; there are no remains of ovarian structure to be seen. Very respectfully,

Surgeon U. S. Army, Curator.

CACSE AND FREQUENCY.

the question will be asked, How is the atresia produced, and how often does it occur? It is caused physiologically by the reduction in size of the uterus which takes place in normal atrophy, where the organ is reduced in some cases to a mere nodule. Patho- 
logically, from cancer, tumors, such as fibroids, catarrbal and other inflammations of cervical endometrium, extension of vaginitis into cervix (particularly senile vaginitis), small polyps causing endocervicitis, post-diphtheritic inflammations, the nse of strong caustics, actual or electric cautery, trauma, and contraction or cicatrization following trachelorrhaphy.

\section{VARIETIES.}

The atresia may occur at the external os or internal os, or may include the entire cervical canal, and in some instances, the cervical canal is obliterated, together with the vaginal portion of the cervix, so that no trace of the cervix is to be found through the speculum, and its site is with difficulty found upon digital examination.

\section{DIAGNOSIS.}

The diagnosis is based upon the age and history of the patient, the size and consistency of the uterus and tubes, and the obstruction discovered by the sound, or the absence of the cervix and os as described above.

\section{TREATMENT}

Open the canal with sound or knife, followed by antiseptic irrigation and douches; keep the canal patulous, by dilation, or excision of cervical tissue when necessary. Operate under strict modern methods. Treat the cavity of the uterus locally with antiseptic applications and irrigations.

\section{DAN(iER.}

Danger arises from faulty asepsis, and perforation of organ by careless or bungling operators. Failure to determine accurately the size of the nterus and direction of the canal will lead to error.

Marylam and liryinia Meflicet. Ion nat, Richmond, 1860, vol. xy, pages
292-295, Art. 4. Report from the Infirmary of the Mredical Coliege of 292-295, Art. 4. Report from the Infirmary of the Medical Coliege of Virginia (service of Dr. McCaw), by Dr. Thomas Hunter. resident physician. "Case of Occlusion of Os Uteri." A negso named Agnes, age 47, Mecaw through the speculum and made to euter the uterus abont the center of its os; was pushed to depth of one and one-half iuchis without entering the cavity of the womb. No further attempts were made, "and moreover, as that period of life had arrived when the menstrual functiou ceased, Nature herself might relieve her without the pain and
risk of an operation." Had two attacks after this. Ends article as folrisk of an operation." Had two attacks after this. Ends article as follows: "In a few days after her last attack she left the Infirmary. She has not been heard from since, but in all probability she has been re-
lieved from all further trouble by the total disappearance of the menstrual function."

Transactions Obstetrical Society of London for the year 1877 , vol. xix, pages 176-177. "A Case of Suppuration of the Uterine Cavity resulting from Occlusion of the Cervix." Dr. Albert Lewis Galabin. "Mary K., and two miscarriages. Menstruation ceased ten years ago. Punctured from the vagina by a small trocar and fluid evacuated was pure pus.

after a few days."

The specimen exhibited shows the occlusion to have been due to the presence of cancerous deposit beginniug about the internal os and not Iianifestly affecting the externul part of the cervix.

Transactions of the American Gy necological Society for the year 1879 Boston, 1880, voi. iv, pages 428-432. "Premature Seulle Obliteration of the Uterine Cervical Canal," by Dr. Henry Campbell, Augusta, Ga. tase 1. - Senile obliteration of the cervical canal with accumulation
within and distension of the uterine cavity. Evacuation by incision and dilatation. The patient a virgin. Called Aug. 4,1876 , to Miss N. H. age 55 , in consultation with Dr. Amory Coffin, of Aiken, S, C. Operated. Discharge iutolerably offensive; it more nearly resembled roten egg efiluvium than anything else; amounted to nearly eight ounces. Jan. offensive discharge from vagina had continued but a few days after operation. Jan. 26 operated again; in ten days uterus appeared to be normal. July 7,1877 , she was in an extremely low condition. Died from irritative fever and exhaustion soon after.

rase 2.-Senile obliteration of cervical canal. Patient a multipara. April 4, 1878 . Mrs. L. 7 ., of South Carolina, age about 58 years; mother of eight or ten children. Youngest about 16. June 26. 1878. Operated: evacuated fluid nearly sixteen onnces, about consistence of thickened
milk, closely resembling in its offensive odor that previously described. Recovery. Health perfect in every particular.

Atlanta Medical Regieter, 188182 , N. S., vol. i, pages 65-73. "Atresia of the Vagina and Uterus." A Clinical Lecture by Dr. A. F. Erich, Balti. more, Md. Professor of Diseases of Women, College of Physicians and Surgeons, Baltimore. "Surgeon in charge of the Maryland Woman's Hospital, etc., says: "Women who have passed the menopause sometimes suffer from an accumulation of mucus or muco-purulent fluid in the uterus, due to the atresia of the os following endometritis or the application of caustics to the cervical canal. In other cases the os may be membrane, completely occluding the os. This condition is not infre- quently seen in prolapse of the uterus. A sound can generally be pusbed (he passage afterward dilated." The indithe retained fluid. keep the tract pervious and restore if possible the functional capacity of the sexual organs.

Chicugo Metiral Journul and Examiner, 1883 . vol. xlvi, pages 394.396 . "Two Cases of Stenosis Uteri with Symptoms of Locomotor Ataxia," by Dr. $O$ Stroinski.

Caxe 1.-M Mr. M. N.. 52 years of age. Operated. Perforated cervix with pesar aud dilated with laminaria tents, then introduced intra-uterine began to disappear and micturition was normal

Crese 2.-Mrs. Anna W., 53 years old, unable to leave bed for the last three months. Operated. Improvement was more rapid in this case; able to do housework after two mouths. Ends as follows: "It is probable that pressure on the uterine nerves, caused by the agglutination of the uterine walls acts reciprocally on the nerrous system of the abdom inal part of the body and on that of the spinal cord.

Transactions of Obstetrical Society of London for 1885 . Iondon, 1886. vol. xxvii, pages 81-83. "Distension of Uterus from Partial Obstruction of Cervix." Dr. A. . . Galabin showed the uterus of a woman, age 61, in which distension of the body with muco-sanguineous fluid was found in association with a partial obstruction of the cervix. The patient died six days after the operation for cancer of the breast. The canal was obstructed by a median septum about three-quarters of an inch long. occulying the lower part of the cervix and the summit of the vagina." Clinical Lectures on the Diseases of Women, delivered in Saint Barchols Her. Matthews Duncan; 4th edition, London. 1859 . \& Churchill. Lecture II, "On Retention of Mucus," puge 65 Atresia may occur at any part of the course of the genital passage: and show you here an example of what happens to be the commonest acquired atresia-atresia of the internal os uteri-coming on in old age, and producing in the specimen I show you, a pyometra, the body of the uterus being

Zeitschrift fur Medicin, Chirur(jie und Geburtshulfe, n. f. v., 1866, pages 2244, 91.100, by Prof. Dr. C. Hennig, Leipzig, "On Atresia of the Uterus." says: "But exceptionally one meets atresia after the climacteric period. though in old age cases occur very often in which the internal os omes together, but does not close entirely (hych whetra ex incolutione (O) 100 females who have passed the filteth year, one will find about twenty-eight with atresia of the internal os, and, doubtless the anomaly to make its appearance. Notwithstanding, I do not mean that one dare perceive senile atresia as a physiologic condition."

Algemeine Hiener. Medizinische Zritung. 1878, vol. xxiii, pages 257-258, Allgemeine thene Aechasableness of the Cervical Canal and Its Treatment." by "Dr. A. Tripier, of Paris: "That the internal os of the cervix is commonly completely obliterated, which Moyer has already laid stress on; that this growing togeiher appears to be normal in old women. Gu; that this glowing togeiner appears to be normal in old women. years old.

"Ueber Atresia der Nichtschwangeren Gebärmutter," by Franz Reder, university of Rebstock, 1860 (Inallgural

"Ueber A tresia der Vagina und des Cterus," by Wright Barnum, Uni"Uity of Jena. 1891 (Inaugural Dissertation). Under "Results and Symptoms:" he divides them into three groups, in the last of which (c) "Results of Atresia After the Menopause," he says: "In the third period we have as a sequel an accumulation of mucus or pus. This is the we have as a seque for hydrometra. This accumulation is serous, mucus, etc." e advises operations in such cases.

"De L'Atrésie du Col de L'Uterus." Thésis by Elisée Riluard, Moutpelier, 1869. Gives two cases: Female aged 55 years, atresia internal os peration complete cure. Female aged 53 , atresia due to abuse

he died and an autopsy was beld. when condition was found. "Sur les Retrecissements de L't terus." Thesis by Dr. J. Henri Pouil of 50 , but does not say that she had ceased menstruating.

ai sur la Rétrécissement du Conduit Ltérin, Considéré Prineipalment au Point de vue du Traitement." Par Godefroy Thermes, Paris 1807. Gives a case of a woman aged 53 years who was suffering from which extended to the neck.

Klinische Mittheilungen aus der ersten Geburtsbilflich-Gynäkologischen Universitats-Klinik in Buda.Pesth, Uber die Jahre 1874-82, Mit Kurzer iibersicht uber die Jabre, 1869-74. Herausgegeben von Dr. Theodor von Kezmarszky, Stuttgart. 1884, page 237, under "Gynäkologische dor von Kezmarszk, stuttgart. 1884, page 237, under "Gynakolog affections, 421, of which 4 were senile atrophy of the uterus.

Die Königliche Universitits, Frauenkinik in München in den Jahren, 18\$4-1890. Trerichte und Studien. Her

For $1884-1590$ inclusive $89 t$; patients in gynecologic portion. In 1884 , ext: For 128 ; 1 18 81,$171 ; 1887,163 ; 1888,169 ; 1889,202 ; 1190,191$. No cases.

OUT-DOOR SERVICE.

Jan. 1, 188;, to Jan. 1, 1886.358 persons; $1886-1890,2,135$ patients treated : in $1886,446: 1887,394 ; 1888,311 ; 1889,133 ; 1890,551$. No case

Rendiconto delle Sale di Ostetricia e di Ginecologia (Anno Scolastico. 1882-83) dirette dal Dr. Giovanni Cosentino, Professore Pareggiato di Ostetricia nella R. Universita di I'alermo e Ginecologo Primario dell Ospedale Civico; Redatto dal Dr. Giuseppe Giglio, Palermo, 1884 . Con-
sultazione Nell Ambulatorio Di Ginecologia. Treated 419 cases. No sultazione Nell Ambulatorio Di

cases of atresia after menopause. 1890, pages 266-267: "Atresia of cervix is rare as a comgenital condition. It is more frequently acquired, and results from the following causes Adbesion of granulations in cervical catarrh (after menopause) and round the base of tumors. The practical point for the practitioner to remember is that it occurs also as part of the physiologic changes which take place after the menopause; 28 per cent of women above 50 years of age liave atresia of the cervix (Hennig)." Page 319: "Senfle atresia of the cervical canal is the result of a localized chronic endometritis. This is one of the physiologic changes which occur after the menopause. In some cases, however, it becomes pathologic ; accumulnti "Diseases of Women," by Dr. Alfred I,. Galabin, 5th edition, London 1893. Page 80: "Acquired uterine atresia usually affects some portion of the cervical canal. It may also be the effect of cervical catarrh through adhesion of the granulations formed on opposite sides of the canal, especially when the passage is no longer kept patent by the flow of
menstrual blood. It is not uncommon, therefore, in old women, espe- 
cially when prolapse of the uterus exists." Page 82: "After the menopuuse the uterus may be filled by mucus fluid (bydrometra), a condition usually resulting from acquired atresia of the cervical canal. I have met with one instance in which the uterus became largely distended by

pus in consequence of an atresia produced by cancer about the internal
os. Advises operation." York, 1892,2 vols. Vol. $i$, pages 532-533: "Acquired atresia. It may also follow the cicatrization of ulcers of the cervix coincident with senile atrophy of the uterus; finally, it may in old women, be due to a tumor in the cervix or lower portion of the body of the uterus. It may occur spontaneously in old age. The results of this obliteration vary as the patient has or has not reached the menopause. If she bas ceased menstruation the lesion usually causes no disturbance unless some cause of septic infection exists in the uterine cavity, causing an accumulation of pus (pyometra) or gas (physometra). I have seen two cases of pyometra from cancer of the body of the uterus and fibroma in aged women. The treatment in such a case consists in incising or punctiring the cervix if it be necessary to disinfect the uterine cavity and then in meeting the indications called for by an existing fibroma or cancer."

"A Practical Treatise on the Diseases of Women," by T. G. Thomas, 6th edition. Eularged and thoroughly revised by Dr. P. T. Munde, Philadelphia, 1891. Page 229 gives as a cause of acquired atresia, senile clares that out of 100 is so very common in old age the age about 28 (over a quarter) suffered from it. Results: It might at first thought be supposed that uterine atresia occurring after the menopause would be as it usually is before puberty, a matter of no moment. As a rule this is so, but there are exceptions to both rules. In the old women a watery secretion sometimes takes place, giving rise to hydrometra; suppurative action may occur, creating pyometra. Advises operation.

"A Practical Treatise on Diseases of Women," by Dr. J. Thorburn Loudon, 1885. Pages 151-152: "It also occasionally happens that, menstruation having ceased, the occluded uterus continues to secrete a quantity of mucus fluid, more or less watery, which distends the organ, giving rise to the same physical signs as hematometra (hydrometra), and in still rarer cases this fluid is or becomes purulent (pyometra) or decomposes, giving rise to the presence of gases (physometra)." Advises operation.

“A Manual of Gynecological Practice," by Dr. A. Duhrssen. Translated by J. Taylor, F. R. C.S, and F. Edge, M.R. C. P., F. R. C. S., London, 1895. Page 85: "In old women an atresia of the internal os is found mucus or pus "(Hydro and pyometra) Page 8s. "Atresia of the interual os is treated by simply passing a sound or trocar through the obstruction.

"Practical Manual of Diseases of Women and Uterine Therapeutics. by H. MacNaughton Joues, M. D., M. Ch., F. R. C. S. I. and E., New York, 1854. Page $355: 1$, causation: 2, acquired. The causes producing acquired atresia are: cervical endometritis, senile atrophy: Advises operation if hydrometra, etc.

"An American Text-Book of Gynecology-Medical and Surgical," edited by Dr. J. M. Baldy, Philadelphia, 1894. Page 585: "Hydrometra, the retention of the secretions from obliteration of the canal

"Landmarks in Gynecology" by Dr. Byron Robinson, Detroit, 1894 Vol. II, page 190: "Hydrometra-it is a condition of late life, when senile or other degeneration arise in the cervix."

"Hand-Book of Gynecological Operations," by A. H. G. Doran, F. R. C S., Philadelphia, 1887. Page 338 gives Breisky's operation for atresia of

the cervix. I'age 75, in speaking of hydrometra, says: "It is a condition almost entirely confined ex necessitate to women who have passed the climacteric period of life, and it very rarely causes the uterus to reach any great size, because the greater part of the secretion of the internal mucus surface is capable of resorption, leaving behind only the more solid elements of the mucus. Simpson narrates a case unusual for it, in which he arew off large quantities of serous fiuid from the cavity of the uterus which had been distended to the size of the fifth or sixth month of pregnancy, the fluid being due to a cancroid tumor at the fundus. In such a case the symptoms would be severe and would necessitate a careful examination. 'The first thought would be to eliminate the possibility of pregnancy and then to open up the canal.

"A Text-Book of the Diseases of Women," by Dr. H. J. Garrigues, Philadelphia, 1894. Page 407: "Closure of the uterus (acquired atresia) but the uterus may also be closed later in life; acquired atresia. Al affection. Etiology: sometimes it is simply due to old age and is especially found in old women suffering from prolapse of the uterus. After the menopause the atresia hardly gives rise to any symptoms unless it is complicated with sume other disease of the womb, especially cancer or fibrome.

"A Hand-Book of the Diseases of Women, Including Diseases of the Bladder and Urethra." by Dr. F. Winckel, of Munich. Authorized trans lation. Edited by Dr. T. Parvin, of Philadelphia, 1889., Page 462: "Among the numerous causes of these are advanced age." Page 465: "Or if there is a retention of the uterine secretion after the menopalise the uterine walls are sometimes thickened but not infrequently they not cite any cases.

"Encyclopedia of the Practice of Medicine," edited by Dr. H. von Ziemssen, vol. $x, 1875$. "Diseases of the Female Sexual Organs," Hand-Buch der Krankheiten des Weibes nebst einer einleitung in Physiologie und Psychologie des Weiblichen Organismus, von Dr. Johann C. G. Jorg, Leipzig, 1831. Page 325 mentions hydrometra as occurring in women after the climacteric, due to stenosis and atresia; recommends operation.

Lehrbuch der Gynikologie, yon Carl (r. Carus, Wien, 1829. Vol. I, page 977 , same as ubove.

Spiegelbilder der Gesunden und Kranken Vaginal Portion und Vagina, von Dr. J. Heitzmann, Wien, 1883. Page 173

Die Tetra in women after the menopanse. und Heilung, von Dr. $R$ Flechsig, Leipzig, 1885. Page 124, under stenosis and atresia of the uterus, mentions hydrometra as occurring after the menopause.

Frau, "Atresia due to senile atrophy of the internal os, is not patbological." Page 184: "Hydrometra occurs mostly in old women who, after the menopause, have atresia of the uterus."

Die Krankheiten der Frauen, von Dr. Heinrich Fritsch, Braunschweig, 1886, 3d edition. Page 191: "In old women cervical atresia occurs but of the a the mucus or pus." (Pyo- metra senilis.) Advises operation. (First edition translated by Isidore Furst, Wood's Library, 1883 .

Hand-Buch der Krankheiten der Weiblichen Geschlechtsorgane, von Dr. Carl Schroeder, Leipzig, 1890. Page 413: "Atresia, mostly of the internal os, we find in old women very often; Hennig found it twentyelght times in 100 r metra the symptoms are not so intense, since the accum the dilation of more slowly and the atrophic, non-functioning uterus in the dion.

Lehrbuch der Frauenkrankheiten, von Dr. F. Winckel, Leipzig, 1890 Page 559: "Cause, old age." Page 567: "If hydro- or pyometra, operate." Compendium der Gynükologie, von Dr. J. Heitzmann, Wien, 1891 Page 215: "In the climacteric, atresia of the internal os does not occur very often, only mucus accumulates with little or no pain. (Hydrometra seniles): contrary to this, mostly through gonorrheal infection a condition is caused, by which an intense

cavity of the nterus." (Pyometra senilis.) Dr. L. de Sinety. Deuxićme edition. Paris, 1844. Page 330 quotes Hennik Manual des Maladies des Femmes, par A. Lutaud, 2

891. Page 36 : "Uterine atresia is sometimes acquired." Traite Pratique de Gyuécologie, par Stéphane Bonnet et Paul Petit. or pyometra. Le Malattie della Donna. Trattato Clinico. Completo del Dottor
Page 359 quotes Hennig same as above.

The Journal of the American MEDICAL Association, vol, xviil, 1892 pages 188-190. "Osteomalacia," by Dr. D. S. Lamb: In the post-mortem of a case made for Dr. Mary Parsons, found this condition and others in which the uterus was 2.25 inehes long; cervix normal, lips still well marked: abscess in fundus one inch in diameter, distinct from uterine canal, filled with cheesy pus; wall of abscess thin, inner surface rough. cellowish cheesy contents; the right cyst was one inch, the leit one

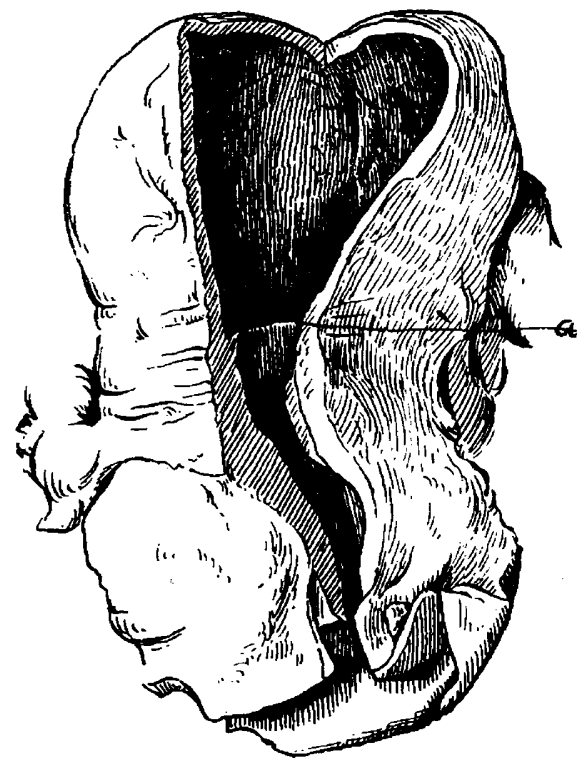

Fig. 4.-The uterus has been opened through the posterior wall

A. Wall of abscess cavity separating the cavity from the canal below.

fourth inch in diameter. Ovaries atrophied, smooth. Some pelvic perioneal adhesions. This is a case attended by Dr. Mary Parsons, the skeleton of which is in the Army Medical Museum, catalogued as No. 10,000 , Pathological Section. Its entire weight is only two pounds and thirteen ounces. The patient was a white woman, single and about 69 confined to bed about twenty-one years. The uterine specimen is catalogued No. 10,011 .

NoTe.-June 25, 1895: The abscess cavity is the much dilated upper portion of the uterine canal, separated from the lower patulous and normal portion by the boundary wall of the abscess cavity; in other words, there is atresia of the canal, caused by the formation of the abscess cavity wall as shown in the diagram. (I would suggest that in the above-mentioned case the atresia was not produced by the abscess, but
by the atresia. H. L. E.J.)

BOOKS CONSULTED IN WHICH THE DISEASE IS NOT MENTIONED.

Dr. Wm. B. Atkinson: The Therapeutics of Gynecology and Obstetrics. Philadelphia, 1880 .

Dr. Headley W. Balls: The Evolution of the Diseases of Women. Lonon, 1894.

Dr. G. W. Bratenahl and Dr. Sinclair Tousey: Gynecology. 1894.

Dr. W. H. Byford and Dr. H. T. Byford: The Practice of Medicine and Surgery Applied to the Diseases and Accidents Incident to Women, 4 th dition. Philadelph1a.1888.

Dr. J.H. Croom: M auual of Minor Gynecological Operations and Alpliances. Edinburgh, 1883 .

Dr.F. H. Davenport: Diseases of Women. A Manual of Non-Surgical Gyoecology. Philadelphia, 1889.

Dr. D. D. Davis: Syllabus of the Lectures on the Theory and Practice of Midwifery and on the Diseases of Women and Children, delivered at niversity College, London, 1839.

Dr. T. A. Emmet: The Principles and Practice of Gynecology. Philadelphia, 1884 .

delohia, 1894 
Dr. Wm. Goodell: Lessons in Gynecology. 1890.

Jir. C. H. Goodwin: Treatment of Diseases of Women, Puerperal and Non-Puerperal. New York, 1884 .

Dr. D. B. Hart: Selected Papers in Gynecology and Obstetrics, Edinburgh and London, 1893.

Dr. A. I. N. Jewers: A Practical Text-Book of the Diseases of Women. Philadelphia. 1888 .

Dr. M. D. Mann: A System of Gynecology. By American authors, two volumes, Philadelphia, 1887 .

Dr. E. Martin and Dr. J. P. Maygrier: Atlas of Gynecology and Obstet ries. Cincinnati, Obio.

Dr. Y. F. Munde: Minor Surgical Gynecology. New York, 1885.

Dr. J. Phillips: Outlines of Diseases Peculiar to Women. London, 1

Dr. J. J. Reynolds: Notes on the Diseases of Women, 4 th edition.

London, 1894 .

Dr.J. Robertson : Essays and Notes on the Pnysiology and Diseases of Women and on Practical Midwifery. Iondon, 1851 .

Dr. A. J.C. Skene: Treatise on the Diseases of Women. New York, 1893. Dr. H. Savage: On the Female Pelvic Organs, 3d edition. London, 1876. Dr. L. Tait: Diseases of Women and Abdominal Surgery. Vol. I, Philadelphia, 1859 .

Cyclopedia of Obstetrics and (iynecology. New York, 1887.

The Student's Hand-Book of Gynecology. Edinburgh, 1893.

Dr. J. Amann: Die Gynäkologische Unterstuchung m1t Jiagnostischen

Anhaltspunkten für Praktische Aerzte and Studirende der Medicin zur

Dr. E. Bjo in die Gynäkologie.

Dr. E. Bjdder and Dr. A. Bidder: Gynükologische Mitheilugen GratuHeinrich Bidder, Professor Emeritus der Physiologie. Berlin, 1894.

Dr. G. Braun : Compendiun der Operativen Gynakologie und Geburtshilfe. Wien, 1860 .

Prof. R. Chrobak: Deutsche Chirurgie-Untersuchung der Weiblichen Genitalien und Allgemeine Gynäkologische Therapie.

Dr. Eichholz: Die Krankheiten der Frauen, Neuwied, a R. Leipzig, 1891.

Dr. H. Fehling: Lehrbuch der Frauenkrankheiten. Stuttgart, 1893. Dr. M. Grechen: Gynakologische Studien und Erfahrungen. Berlin W. and Neuwied a / $R, 1891$.

Dr. H. Graetzer: Medicinische Übungsbücher, 53 Typen aus dem Diete der Gynäkologie and Geburtshülfe. Basel, 1893

Einschiuss der aynakol Untersuchungslehre Stuttgart, 1886 .

Dr. zig und Wien, 1858 .

Dr. O. Kustner: Grundzüge der Gynükologie. Jena, 1893.

Dr. Lahs : Vorträge un Abhandlungen zur Tokologie und Gynäkologie.

Marburg, 1884

Dr. H. Löhlein: Gynäkologische Tagesfragennach Beobachtungen in der Giessener Universituits, Frauenklinik. Wiesbaden, 1891.

Dr.C.C.T. Litzmann : Erkenntniss und Behandlung der Frauenkrank heiten im Allgemeinen. Berlin, 1886 .

Dr. A. Murtin: Pathologie und Therapie Der Frauenkrankheiten

wien und Leipzig, 1893

Dr. R. Olshausen: Klinische Beitrage zur Gynäkologie und Geburt-

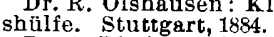

Dr. A. Rheinstaedter: Praktische Grundzïge der Gynükologie. Berlin,

1886. A Sturn: Zur Verhütung der Frauenkrankheiten Stuttgart 1883

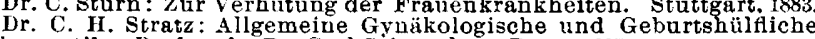
Diagnostik. Preface by Dr. Carl Schroeder. Bonn, 1887.

Dr. H. Schaefer: Die Operative Gynäkologie des Neunzehnten Jahr hunderts. Inaugural Dissertation. Wurzburg, 188s.

Dr. J. Veit: Gynükologische Diagnostik. Stuttgart, 1890.

Dr. J. Veit: Gynükologische Diagnostik. Stuttgart, 1890.
Dr. F. v. Herff: Die Gynäkologie des Franz v. Piemont. Giessen, 1843.

Dr. F. v. Herff : Die Gynäkologie des Franz v. Piemont. Giessen, 1843.
Dr. J. v. Saxiuger: Mitheilnngen aus der Geburtshülflich-Gynäkolo-

Dr. J. v. Saxiager: Mitheilnngen aus der Gebr
gischen Klinik zu Tübingen. Tübingen, 1884 .

Dr. Maria von Thilo: Hand-Buch der Hygiene der Frau. Neuchatel, 1891.

Dr. E. v. Braun-Fernwald und Dr. F, Kreissl: Klinische Beitrage zur Manuellen Behandlung der Frauenkrankbeiten. Wien, 1889.

Dr. P. Z weifel. Vorlesunen üer Klinite Dr. P. Zweifel: Vorlesungen uber Klinische Gynakologie. Berlin,1892. Hryakologische Klinik Herausgegeben yon $\mathrm{r}$. Wilhelm Alexande Klinfk an der Kaiser-Wilhelm's Universitet Stren u rynkologische Klinfk an der Kaiser-Wilhelm's Universitat Strassburg, Strasshurg, 1885.
Dr. J. B. H. Bonafous : Considerations Physiologiques et Generales sur les diverses époques de la vie de la femme. Paris. 1s17.

Dr. P. L. M. Clément: Considerations Physiologiques sur Ies diverses rpoques de la vie des femmes. Paris, 1808 .

"poques de la vie des femmes. Paris, 1808. Traitement imployés en Gynécologie. Paris. 1890.

Dr. M. Gonzalez: Indications et Contre-Indications de L'Ignipuncture du col de I'Uterus. I'aris, 1884 .

Dr. M. Guibout: Traite Clinique et Pratique des Maladies des Femmes. Paris, 1886 .

Dr. Goupil: La Femme ses Fonctions et ses Maladies. Paris.

Dr. Goupl. Jacobs: Institut Gyncologique. Stafistiques des Operations. Pratiqués en 1889-1890-1891. Bruxelles, 1892.

Dr. J. Hatin: Cours Complet D'Accouchemens et de Maladies des remmes et des Enfans, Paris, 1835.

Dr. Keiffer: Travaux Cliniques de Gynécologie et D'Obstetrique, 1893-4. liruxelles, 1894 .

Dr.S. V.A. Navet: Propositions sur le Temperament de le Femme, sur sa Menstruation et sur son age Critijue. Paris, 1830.

Vulliet et Iutaud; Lecons de Gynécologie Opératoire. Paris, 1890,2d edition.

Dr. F. Voisenet: Traite Pratique des Maladies des Femmes a L'Usage des gens du Monde. Paris, 1881 .

Dr. L. Verrier: Guide du Medecin Praticien et de la Sage Femme pour le Diagnostic et le Traitement des Maladies Uterines survi d'un Appendice sur la Sterilite. Paris, 1876.

Vabé: Manual des Maladies des Femmes. Paris, 1894

Sorani Ephesii : Liber de Mulieribus Affectionibus Recensuit et

Latine Interpretatus Est. 1860 .

Mauuel de Therapentique Gynècologique.

Maulel de Therapeutique Gynecologique.
Dr. A. Auvard : Indications Therapeutiques.

Dr. Edmund Caubet: Therapeutique Generale et Hygiene.

Dr. de Kervilly: Medication Locale.

jr. Berlin: Operations.

Dr. Berlin : Operations.
Dr. Touvenaint : Electricite.

Dr. Touvenaint : Electricite.

Dr. A. Ozenne: Hydrotherapie et Eaux Minerales. Paris, 1894.

There are no standard text-books in the Spanish or Russian ang a

except translations of those already quoted.
CONCLUSIONS.

From what has appeared above we may draw the following conclusions:

1. Pathologic atresia of the uterine canal after the menopause is a condition which exists more frequently than is usually supposed, produces symptoms which have not been thoroughly appreciated, and may lead to error in diagnosis in some cases.

2. The subject has not been carefully studied, or correctly treated in the past.

3 . The symptoms mislead by directing attention to the nervous system more particularly than to the true seat of disease.

4. Atresia, or more correctly speaking, obliteration of the uterine canal, is a physiologic condition, only after complete atrophy of the body of the uterus and its endometrium.

5. The uterus, during the menopause, and until completely atrophied, should be kept under careful observation, all inflammatory, catarrhal, and other abnormal conditions treated and cured, and the canal kept pervious by the passage of a suitable sound to facilitate drainage.

6. All cases of atresia of the cervix, where complete atrophy of the uterus has not taken place, should be operated upon at once, even in advance of symptoms.

7. Operation is beneficial by preventing or relieving distressing symptoms, and is absolutely free from danger when performed with modern surgical precautions.

8. Many obscure symptoms occurring during, and after, the menopause, are produced by retention of fluid and débris from atresia of the cervical canal, which can be promptly relieved by the treatment advised.

9. This subject is of the greatest importance and deserves a thorough investigation by the medical profession.

\section{PECULIARITIES OF COLOMBIAN LEPROSY. \\ BY ALBERT S. ASHMEAD, M.D. NEW YORK.}

Leprosy in Colombia dates from very remote times, though no light is thrown over its origin. According to Father Velasco, in the middle of the last century a lazaretto was founded in Cali.

I find in an article of the Anales de la Academia Nacional de Medicina, Bogota, 1894, under the signature of Dr. Alfredo Garcés, several points which represent Colombian leprosy in a rather peculiar manner.

1. According to the information obtained from patients, and the opinion of the Doctor himself, the disease originates mostly, if not always, in a cold ; exposure to rain, sudden cooling after strong perspiration, sojourn in damp rooms, especially during confinement, bathing in a brook being heated, passing from a warm climate to colder altitudes, etc. These accidents are all followed by the wheals of urticaria. From the urticaria, leprosy is developed. Most of the patients attribute their malady to a cold. Some say that they went out into the cold air; that they have been exposed to a draught, to a shower; that they have gone into the water while heated. One of them said to me: "I was sleeping in the evening; I was awakened suddenly and went out at once, heated and perspiring, into a cold hallway; I got a spass- 